\title{
Modeling Lean and Agile Approaches: A Western Canadian Forest Company Case Study
}

\author{
Francisco P. Vergara ${ }^{1, *}$, Cristian D. Palma ${ }^{2}$ (D) and John Nelson ${ }^{3}$ \\ 1 Faculty of Engineering, Department of Wood Engineering, Universidad del Bío-Bío, \\ Concepcion 4030000, Chile \\ 2 Facultad de Ingeniería, Centro de Investigación en Sustentabilidad y Gestión Estratégica de Recursos, \\ Universidad del Desarrollo, Concepcion 4030000, Chile; cristianpalma@ingenieros.udd.cl \\ 3 Forestry Faculty, The University of British Columbia, Vancouver, BC V6T1Z4, Canada; john.nelson@ubc.ca \\ * Correspondence: fvergara@ubiobio.cl; Tel.: +56-41-311-1370
}

Received: 17 August 2018; Accepted: 24 August 2018; Published: 31 August 2018

\begin{abstract}
In the forest supply chain of the coast of British Columbia, the material flows are directed toward the push production of commodity products. This industry has not adopted lean and agile principles due to unclear economic impacts on the supply chain in changing market conditions. We tested the ability of lean and agile principles to improve performance in the coastal integrated forest industry. Mixed integer programming formulations were subject to over-under production capacity, and over-under demand fulfillment penalties to emulate agile, lean, and hybrid manufacturing environments, when solving the planning problem. Assuming that the coastal integrated forest industry performs as a hybrid environment, the profit results of each manufacturing environment were judged. The results show that, opportunities for profit improvement were $11 \%$ for adopting an agile environment when demand was stable with low variation and large batches of production. However, profit improvement was non-existent when the same demand attributes apply but with high variation. The opportunities for profit improvement were $12 \%$ when an agile environment or lean environment was adopted when demand was stable with low variation and small batches of production. However, opportunities for profit improvements of $15 \%$ existed for adopting an agile environment when demand was unstable with high variation and small batches of production.
\end{abstract}

Keywords: forest-to-lumber; supply chain; planning; lean; agile; hybrid; mathematical programming

\section{Introduction}

A large number of companies are thinking to switch to lean and agile manufacturing systems [1]. Supply chain managers strongly rely on their ability to reduce costs and waste, increase customer service, and provide a competitive advantage. Lean and agile manufacturing systems are multi-dimensional approaches that contain a variety of management practices. Resources efficiency and high performance are key stones of lean manufacturing, while the capabilities of addressing customer requirements are on the side of agile manufacturing [2].

Lean manufacturing can be described as developing a value stream to eliminate all waste including time, and ensure a level schedule [3]. A manufacturing process working away from variation and uncertainty can be defined as a level schedule, which ensures high capacity utilization, thus leading to lower manufacturing costs. Consequently, lean manufacturing is a system mainly that is focused on increasing the efficiency of operations. Contrarily, [4] agile manufacturing is a system that is capable of operating profitably in a competitive environment, where customer demands continuously and unpredictably change. Agility reacts quickly and effectively to changing customer needs in a volatile marketplace; it is able to handle variety and introduce new products. The ability to introduce 
highly customized products is a key component of agile systems, which is addressed with capabilities to change between products without significant investment. However, such flexibility increases manufacturing and transportation costs [5]. Thus, a lean manufacturing approach is predominant in production systems that are focused on products that satisfy basic needs, where the products demand is stable with large life cycles. Contrarily, an agile manufacturing approach is predominant in production systems that advocate innovative products that satisfy sophisticated needs, where the products demand is almost unpredictable with short life cycles [6].

The adoption of emergent manufacturing systems principles should be subject to accurate economic analyses. However, there is no substantive economic evidence at the bottom of the economic forest company level to support their implementation. Hence, we reviewed the related literature to suggest a framework to address manufacturing system evaluation.

This type of systems evaluations have been performed using discrete event simulation (DES) models, measuring their advantages in different industries when adopting lean, agile, and hybrid principles, but only at the shop floor level of the factory [1]. On the other hand, mixed-integer linear programming (MIP) models have been used to elucidate the ability of agile principles in order to improve the economic performance for supply chain network design. Strategic and tactical decisions such as opening facilities and their capacities, and selecting transportation modes were considered [7]. Although the previous research is novel, it does not address the short-term aggregate planning problem where the ability of the manufacturing system must be measured.

Lean, agile, and hybrid manufacturing are philosophies that are easy to understand; however, their complexity appears during implementation. Goldsby et al. [1] modeled a supply chain (SC) for lean, agile, and hybrid manufacturing to evaluate their benefits and tradeoffs. A DES model was used to simulate the SC. The results showed costs, lead times, and inventory tradeoff between manufacturing environments. However, there was no mention of how product demand patterns should be assessed in order to better represent the manufacturing philosophies. Another attempt to quantify lean manufacturing benefits was made by Al-Aomar et al. [8]. The manufacturing system was modeled with DES, and a tabu search approach (TS) was used to find the model parameters that optimized the lean measures (e.g., work in process (WIP) and lead times (LT)). As lean measures with one objective could be contradictory, a multi-objective cost function to rank solutions at each TS step was applied. Although this approach considered the effect of lean techniques on profits, it is not clear how this method balanced lean measures, as the author claimed.

Despite efforts to measure the benefits of manufacturing systems with models, most research has been conducted for only one facility, regardless of the effect on the SC, and without considering demand changes [9]. Until now, researchers have been applying DES, value stream mapping (VSM), experimental design, and TS to find the setting that optimizes the balance between manufacturing measures. These approaches have been successful when modeling floor variables, given their stochastic nature. Unfortunately, these efforts fail to explicitly measure the impact of the manufacturing principles on economic performance. On the other hand, MIP have been used to optimize short-term production planning [10], where policies to manage inventory, production capacity, customer service, and lead times can be easily tested. Thus, the mid and short-term production planning problem represents a suitable scenario for testing lean, agile, and hybrid manufacturing environments.

The SC uses raw materials, which are resources with limited capacities to produce products that satisfy customer demand, optimizing the tradeoff between setup and inventory holding costs [11]. The problem has been solved with MIP formulations. Furthermore, Billington et al. [12] suggest that the problem begins when material requirement planning (MRP) systems assume no constraints for facilities; hence, any amount of production is presumed to be possible in each facility. However, lead times (setup and production time) can increase due to bottleneck operations, triggering unpredictable lead times. This problem has been called a capacity-constrained production scheduling problem.

Depending on the manufacturing system, different modeling approaches can be applied. A tradeoff analysis between setup and holding inventory costs should be conducted [10]. Multiple 
products and capacity constraints increase the complexity of the problem. The MIP formulations usually focus on minimizing the setup and holding inventory costs, which are subject to material balance constraints, plus capacity and market constraints. However, in practice, the number of binary and continuous variables (i.e., production quantities by product and setup cost) makes the problem intractable with exact algorithms.

MRP calculates the requirements for all items, including raw materials, parts, components, and subassemblies. MRP determination is based on master planning scheduling, capacity requirement planning, and lot-sizing determinations. Lot-sizing decisions may be made based on previous requirements, and always consider materials, machines, and labor constraints. If there are capacity constraints, this problem could become a single or multiple-level capacitated lot-sizing problem [13].

In this context, the well-defined and rich literature on lean tools and methods is contradicted by a few documented quantitative implementations [14] in which the value of lean manufacturing using DES and VSM was tested. A pull strategy to reduce WIP and LT in relation to a push strategy (i.e., large WIP and LT) was assessed, but there are no details on how the pull future state was developed.

Although there is evidence that lean manufacturing techniques (i.e., Just In Time (JIT), total preventive maintenance (TPM), and cellular manufacturing) improve performance in discrete manufacturing, evidence on continuous production is scarce. Aldulmalek et al. [15] performed an analysis of a continuous manufacturing process based on DES, VSM, and historical data. They introduced buffers and scheduling around the bottleneck work station. Later, a DES was run and set up with two levels of TPM, two setup times, and push and hybrid pull manufacturing. Their results showed that pull hybrid manufacturing and TPM trigger significant lead-time reductions, as well as strong reductions in WIP.

Consequently, we sorted a hierarchically and translated lean, agile, and hybrid principles into planning drivers. As a matter of fact, the literature on manufacturing systems is extensive, yet few quantitative implementations can be found, and almost no publications are available for forest industry applications. Meanwhile, not all of the drivers that were mentioned in the literature can be translated and used in a mathematical formulation. We summarized the key drivers based on a large but not extensive literature review, as shown in Table 1 (detailed information can be found at Hallgren et al. [2,3,6,16-21]. Translation of the drivers was applied later on the model formulation of each manufacturing environment (ME).

Table 1. Attributes of lean, agile, and hybrid manufacturing supply chain (SC) drivers.

\begin{tabular}{|c|c|c|c|}
\hline Driver & Lean & Agile & Hybrid \\
\hline SC strategy & $\begin{array}{l}\text { Costs leadership, zero waste, } \\
\text { flexibility and incremental } \\
\text { improvements for existing } \\
\text { product production. }\end{array}$ & $\begin{array}{l}\text { Differentiation responsiveness, } \\
\text { site of inventory capacity: } \\
\text { responsiveness. Provides } \\
\text { customized products with short } \\
\text { lead times by reducing the } \\
\text { costs of variety. }\end{array}$ & $\begin{array}{l}\text { Mass customization by } \\
\text { postponing product } \\
\text { differentiation until } \\
\text { final assembly. }\end{array}$ \\
\hline Product attributes & $\begin{array}{l}\text { Functional commodity: Highly } \\
\text { predictable, long life cycles } \\
\text { (e.g., a staple). }\end{array}$ & $\begin{array}{l}\text { Innovative: uncertain demand, } \\
\text { short life cycles } \\
\text { (e.g., a customized laptop). }\end{array}$ & $\begin{array}{l}\text { Mixed portfolio: functional and } \\
\text { innovative components. } \\
\text { Long-short life cycles } \\
\text { (e.g., a car). }\end{array}$ \\
\hline Volume-variety & Large volumes of low variety. & Small volumes of high variety. & Both. \\
\hline Demand & Stable and predictable. & Unstable and unpredictable. & Both. \\
\hline Manufacturing focus & $\begin{array}{l}\text { Maintains high average utilization } \\
\text { rate. Level strategy. }\end{array}$ & $\begin{array}{l}\text { Deploys excess buffer capacity to } \\
\text { ensure that raw materials are } \\
\text { available to manufacture. } \\
\text { Chase strategy. }\end{array}$ & $\begin{array}{l}\text { Part chase strategy and part } \\
\text { level strategy. }\end{array}$ \\
\hline Back orders & Allowed but penalized. & Not allowed or highly penalized. & Both mixed. \\
\hline Inventory policy & $\begin{array}{l}\text { Generates high turnover and } \\
\text { minimize inventory. }\end{array}$ & $\begin{array}{l}\text { Deploys significant stocks of parts } \\
\text { to tide over unpredictable } \\
\text { market needs. }\end{array}$ & $\begin{array}{l}\text { Minimizes functional } \\
\text { component inventories. }\end{array}$ \\
\hline Lead time focus & $\begin{array}{l}\text { Shorten lead times as long as it does } \\
\text { not increase cost. }\end{array}$ & $\begin{array}{l}\text { Invests aggressively in ways to } \\
\text { reduce lead times. }\end{array}$ & $\begin{array}{l}\text { Lean at component level. } \\
\text { However, at the product level, } \\
\text { follows agile focus. }\end{array}$ \\
\hline Decoupling Point (DP) & At warehouse site & At manufacturing site & At manufacturing site \\
\hline
\end{tabular}


The current manufacturing system of the British Columbia forest industry lacks a differentiation of manufacturing systems by product demand, assuming that a high rate of utilization and increasing throughput are good enough to keep the competitiveness [22]. This industry does not recognize the ability of an agile system to capture higher value when producing highly customized lumber products. However, due to the changeable lumber market conditions, it is necessary to test emerging manufacturing systems to explore the benefits for this industry.

The objective of this research was to determine the impact on profits due to the decision of changing the manufacturing system. We first translated manufacturing system soft drivers into hard mathematical constraints. Second, we formulated three MIP optimization models that represent lean, agile, and hybrid manufacturing systems to solve the forest-to-lumber planning problem. Third, these models were applied under different lumber demand scenarios to represent the variability faced by the forest industry $[1,6]$. A Coastal British Columbia integrated forest company was chosen as the case study. The aim of this study was to explore the relationships between lean-agile-hybrid drivers and decision outcomes, highlighting their benefits and tradeoffs. To our knowledge, this is the first initiative in which lean, agile, and hybrid manufacturing systems have been evaluated and compared based on soft drivers translated into hard constraints to be modeled with mathematical programming. This study first provides descriptions of the essential drivers of the manufacturing systems, previous research, and a detailed case study. Then, a methodology to model the manufacturing principles is explained, followed by the results of the assessment of the performance of the manufacturing environment. The final sections contain discussion and conclusions, where highlights and conclusions on selecting manufacturing principles are explained.

\section{Materials and Methods}

For better understanding, this section was divided into three sections. First is the case study, where we explain its singularities and sources of data. Second, the formulation of models was conceptually addressed, where we translate the manufacturing drivers into mathematical programming models. Third, we explain how the lumber demand scenarios were developed, which helped to recreate lumber demand behaviors based on order sizes and variability inside the order.

\subsection{The Case Study}

The forest-to-lumber SC planning problem was formulated keeping in mind an integrated BC Coastal forest SC, where harvesting, sort-yarding, and sawmilling operations do not always happen simultaneously [22]. A year-based forest operation begins with logging, and then the logs for sawmilling are sorted by species, grade, and hauled by ground or water directly to forest industries. Downstream, sawmills extract the highest lumber grades possible from logs to produce commodities and customized lumber products [23]. In terms of sales, when construction lumber grades are traded, wholesalers tend to be tolerant of an over/under fulfillment of orders. However, when trading high-grade lumber, industrial and wholesaler customers are less tolerant (i.e., there are high penalizations for missing targets). The focus in coastal BC is to create value while maintaining high volume and value recoveries and capacity utilization. Consequently, for the purpose of this study, a year of operation was considered as the time window. Accordingly, a planning horizon of one year divided into four periods was chosen (four quarters). The problem can be divided into procurement planning and lumber planning, where loggers carry out harvesting plans in advance and push stems and logs to sort yards. Then, sawmills buy log sorts depending on lumber sales orders, which is why the decoupling point of this SC is located at the sort yards (Figure 1). 


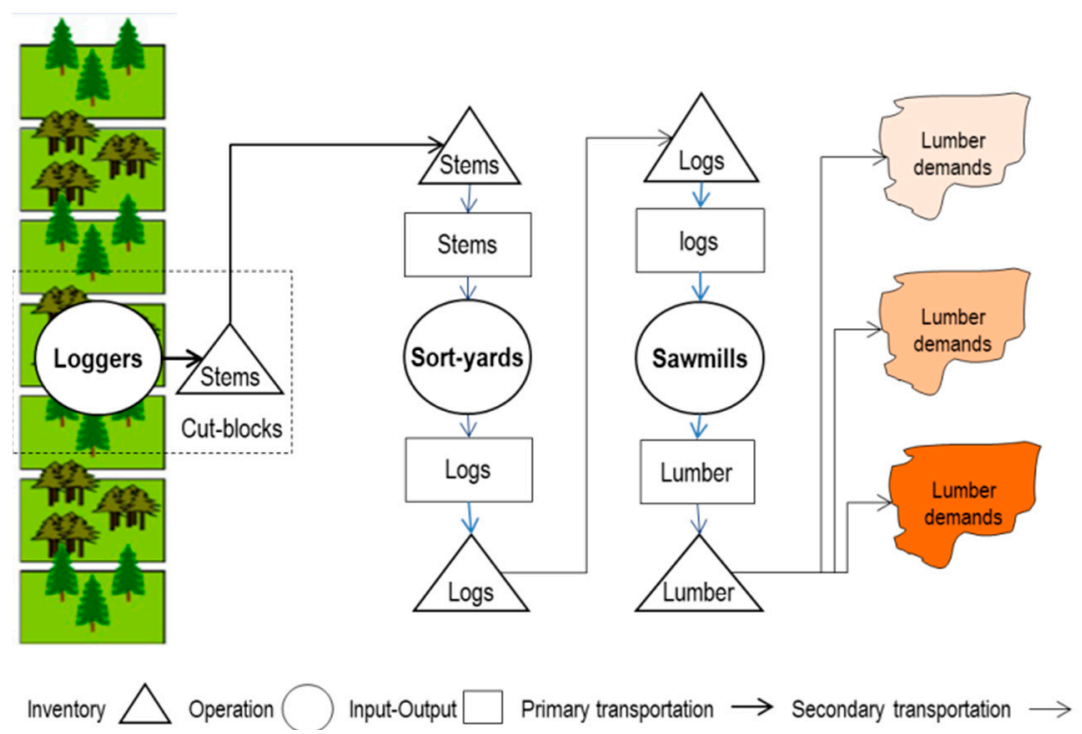

Figure 1. Forest to lumber British Columbia (BC) coastal supply chain case study.

A case study provides the data for forest inventory yields, harvesting costs, log-to-lumber yields, manufacturing costs, lumber prices, and sales orders, and such information was extracted from publicly available annual financial reports from a British Columbia (BC) coastal forest integrated company [24].

\subsection{Formulation of Models}

The soft drivers of manufacturing principles were translated into hard drivers to model the problem. The SC strategy driver of the ME was considered as the central driver and used as the objective function. The manufacturing focus and inventory policy were translated into capacity usage penalty policies. The backorder and lead time focus were translated into demand satisfaction penalty policies. Product attributes, volume, and variety were considered as lumber demand scenarios. The agile, lean and BC-SC formulations included the possibility of lumber interchanges between sawmills and sawmilling outsourcing. The lean approach used a level manufacturing strategy, which was applied as a capacity constraint to ensure that at least a minimum level of capacity must be utilized. The agile approach used a chase manufacturing strategy, which was applied as a capacity constraint to ensure a higher flexibility of capacity usage [5]. The BC-SC used mixed capacity constraints, which was a level strategy for the timber supply problem, and a chase strategy for the lumber manufacturing problem (Table 2). Two additional features were added: (1) applied penalties when lumber production was below or exceeded demand, and (2) applied penalties when capacity (i.e., time availability) was exceeded or was not completely used over a period by loggers, sort yards, and sawmills. In terms of demand satisfaction, over and under demand were heavily penalized under the agile approach, moderately penalized under the BC-SC approach, and lightly penalized under the lean approach. In terms of capacity, over and underproduction capacity was heavily penalized under the lean approach, moderately penalized under the BC-SC approach, and lightly penalized under the agile approach. 
Table 2. Summary of manufacturing environment model formulations. ME: manufacturing environment.

\begin{tabular}{cllll}
\hline ME Formulation & $\begin{array}{c}\text { Central } \\
\text { Manufacturing } \\
\text { Principle Applied }\end{array}$ & $\begin{array}{c}\text { Demand } \\
\text { Satisfaction } \\
\text { Penalty Policy }\end{array}$ & $\begin{array}{c}\text { Capacity Usage } \\
\text { Penalty Policy }\end{array}$ & Objective Function \\
Agile & $\begin{array}{l}\text { Reduces the cost of } \\
\text { variety to create the } \\
\text { highest possible value. }\end{array}$ & $\begin{array}{l}\text { Allows a tiny \% of } \\
\text { lumber demand to } \\
\text { be over or } \\
\text { under demand. }\end{array}$ & $\begin{array}{l}\text { Emulates a time flexibility } \\
\text { policy and production is set } \\
\text { to match the demand and } \\
\text { does not carry any leftover } \\
\text { products (CHASE strategy). }\end{array}$ & $\begin{array}{l}\text { Creating maximum value. } \\
\text { Thus, we applied a profit } \\
\text { max. objective function. }\end{array}$ \\
\hline Hybrid: BC-SC & $\begin{array}{l}\text { Profit max by } \\
\text { harvesting the highest } \\
\text { value forest resources } \\
\text { and satisfying } \\
\text { lumber demand. }\end{array}$ & $\begin{array}{l}\text { BC-SC assumed to } \\
\text { be middle ground, } \\
\text { because it produces } \\
\text { a mixed portfolio } \\
\text { of lumber. }\end{array}$ & $\begin{array}{l}\text { LEVEL Production is a } \\
\text { strategy that produces the } \\
\text { same number of units } \\
\text { equally. } \\
\text { LEVEL for procurement, } \\
\text { and CHASE for sawmilling. }\end{array}$ & $\begin{array}{l}\text { DP at sort-yards; } \\
\text { thus, harvesting and } \\
\text { sort-yards minimize costs, } \\
\text { satisfying log demand. } \\
\text { Sawmills max. Profit, } \\
\text { satisfying lumber demand. }\end{array}$ \\
\hline Lean & $\begin{array}{l}\text { SC cost minimization } \\
\text { reduces all forms of } \\
\text { waste (i.e., Muda) } \\
\text { through the SC. }\end{array}$ & $\begin{array}{l}\text { Allows the highest } \\
\text { \% of lumber } \\
\text { demand, which can } \\
\text { be over or } \\
\text { under demand. }\end{array}$ & $\begin{array}{l}\text { The penalization emulates } \\
\text { a LEVEL strategy. }\end{array}$ & $\begin{array}{l}\text { Focused on cost min.; } \\
\text { thus, a cost minimization } \\
\text { objective function } \\
\text { was applied. }\end{array}$ \\
\hline
\end{tabular}

The objective function for agile maximizes profit $\left(1^{\mathrm{A}}\right)$. Its components are: lumber and chip incomes, penalized incomes for overproduction, less operational costs, and cost penalties for below-demand lumber production, and cost penalties for over/under capacity usage. The objective function for lean minimizes $\operatorname{cost}\left(1^{\mathrm{L}}\right)$ and contains the same components as the objective function for the agile approach. The BC-SC was divided into two problems: (1) timber supply and (2) lumber manufacturing. In order to compare this formulation with the other two, it was assumed that procurement areas transfer logs to the lumber production area with no profits. The timber supply problem satisfies a forecasted log demand; the log production solution was used to solve the lumber manufacturing problem. The objective function of the timber supply problem minimized $\operatorname{cost}\left(1^{\mathrm{T}}\right)$. Its components were: operational costs and cost penalties for over/under capacity usage in logging and sort yard operations. The lumber manufacturing problem had a profit maximization objective function $\left(1^{\mathrm{W}}\right)$, and solved the lumber planning problem. The components of the objective function were: lumber and chip incomes, penalized incomes for overproduction, log costs, operational costs, cost penalties for under-demand lumber production, and cost penalties for over/under capacity in sawmilling operations (please see Tables A1-A7 in Appendix A for full formulations).

\subsection{Lumber Demand Scenarios}

We considered that demand variation is a key factor in manufacturing principles selection [25]; accordingly, we used publicly available information to guide the rate of variation introduced to all of the families of lumber products demand. Only one period of lumber demand was forecast. Demand variations were made to simulate demand changes through time. Random variations were made to lumber product demand volume forecasts. Four lumber demand scenarios (LDS) plus a base case were created, representing combinations of production batch sizes and varieties of products. The scenarios are: (1) Base_LD: demand by grades and species, based on BC companies' public annual reports; (2) LB_LV: large batch and low variety of products demanded; (3) LB_HV: large batch and high variety of products demanded; (4) SB_LV: small batch and low variety of products demanded, and (5) SB_HV: small batch and high variety of products demanded (Table 3). Scenarios were processed producing 30 sets of values per scenario, except for the Base_LD, which contained only one set. All of the scenarios were fed to four optimization models representing each of the ME, which were run in ILOG CPLEX Studio 12.0. 
Table 3. Lumber demand scenarios explanation.

\begin{tabular}{|c|c|c|}
\hline \multicolumn{2}{|c|}{ Lumber Demand Scenarios } & \multirow{2}{*}{$\begin{array}{l}\text { Description of the Scenario } \\
\text { Lumber demand by grades and species, based on BC } \\
\text { companies' public annual reports. }\end{array}$} \\
\hline i. & $\begin{array}{l}\text { Base_LD: Base lumber } \\
\text { products demand. }\end{array}$ & \\
\hline ii. & $\begin{array}{l}\text { LB_LV: Large batches and low } \\
\text { variation of lumber } \\
\text { products demanded. }\end{array}$ & $\begin{array}{l}\text { Large batch and low variety of lumber products demanded, } \\
\text { obtained by multiplying the original lumber demand data by } \\
\text { a random binary number. This arrangement ensures large } \\
\text { values similar to Base_LD, but when multiplied by a random } \\
\text { binary number, the variation was reduced, because when the } \\
\text { binary random number takes a zero value, it makes demand } \\
\text { zero as well. }\end{array}$ \\
\hline iii. & $\begin{array}{l}\text { LB_HV: Large batches and high } \\
\text { variation of lumber } \\
\text { products demanded. }\end{array}$ & $\begin{array}{l}\text { Large batch and high variety of lumber products demanded, } \\
\text { obtained by multiplying the original lumber demand data by } \\
\text { a continuous random number generated between } 0 \text { and } 1 \text { plus } \\
0.25 \text {. This arrangement ensured large values similar to } \\
\text { Base_LD, or even bigger, but all are non-zero values, } \\
\text { because continuous random numbers were used. This means } \\
\text { that all of the values exist, thus ensuring high variation. }\end{array}$ \\
\hline iv. & $\begin{array}{l}\text { SB_LV: Small batches and low } \\
\text { variation of lumber } \\
\text { products demanded }\end{array}$ & $\begin{array}{l}\text { Small batch and low variety of lumber products demanded, } \\
\text { obtained by multiplying the original lumber demand data by } \\
\text { a random binary number, and by a continuous random } \\
\text { number generated between } 0 \text { and } 1 \text {. This arrangement ensured } \\
\text { lower values in comparison with Base_LD, or at most the same, } \\
\text { but the variation was reduced. }\end{array}$ \\
\hline v. & $\begin{array}{l}\text { SB_HV: Small batches and high } \\
\text { variation of lumber } \\
\text { products demanded. }\end{array}$ & $\begin{array}{l}\text { Small batch and high variety of lumber product demanded, } \\
\text { obtained by multiplying the original lumber demand data by } \\
\text { a continuous random number generated between } 0 \text { and } 1 . \\
\text { This arrangement ensured lower values in comparison with } \\
\text { Base_LD, or at most the same, but all are non-zero values } \\
\text { ensuring high variety }\end{array}$ \\
\hline
\end{tabular}

\section{Results}

For the sake of simplicity, the averages of the optimization models' economic outcomes were aggregated by: manufacturing environment, batch sizes, and demand variation inside the batch. Incomes for the lumber demand scenarios were similar; however, operation costs guided by manufacturing drivers determined different profit and performances (see Table A8, and Figure 2). A descriptive results analysis per ME and LDS follows.

\section{Results for MEs}

On average, the agile approach was the most profitable approach, followed by lean (3.9\% below agile) and BC-SC (6.4\% below agile). Regardless of the variation, for large batches, agile was still the most profitable, followed by lean (1.6\% below agile) and BC-SC (6.3\% below agile). For large batches with low variation, the agile and lean approaches obtained almost equal profits, followed by BC-SC (11.1\% below agile and lean). For high variation, agile and lean profits were almost equal, followed closely by BC-SC (2.6\% below lean and agile). Regardless of the variation, the differences were larger for small batches than for large batches, where the agile approach remained the most profitable, followed by the lean (7.1\% below) and BC-SC (13.8\% below) approaches. For small batches with low variation, agile still produced the highest profits, followed by the lean $(6.1 \%$ below $)$ approach and then the BC-SC (12.1\% below) approach. For high variation, the differences were larger, with agile being the most profitable, followed by lean ( $8.0 \%$ below) and then BC-SC (15.5\% below). 
The agile approach led to lower harvest levels, followed by the lean and BC-SC approaches. The timber volume supplied to the sawmill followed the same trend. As a consequence, procurement and manufacturing costs followed the same order, and because the lumber demand data were the same in each LDS, incomes were similar for the agile, lean, and BC-SC approaches, although the BC-SC and lean approaches had higher costs. Over and under-capacity costs were not significant due to the low allowable capacity deviation between periods.

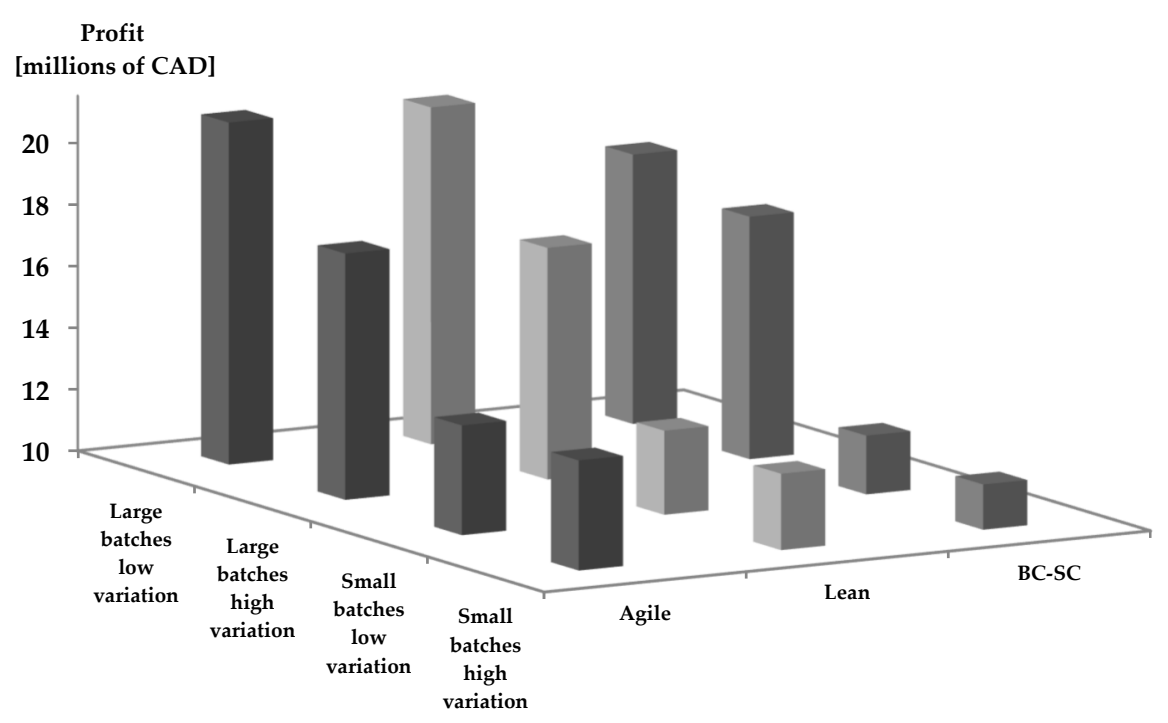

Figure 2. Profits variation between MEs and lumber demand scenarios (LDSs).

In our formulations, overproduction was paid for with lower prices, while underproduction was penalized by charging a cost for the underproduction, which was determined by multiplying the volume of underproduction by a fraction of the lumber price. This mechanism was efficient at controlling production, and brought flexibility that was translated to a customer service emphasis in all of the approaches. The agile approach had the smallest magnitude of lumber over and underproduction, with the exception of large batches with low variation. Lumber production was mostly below lumber demand. The lean approach produced large volumes over and under the demand for most of the small and large batches. The BC-SC approach produced large over-demand volumes for most of the small and large batches, with the exception of large batches with low variation.

In terms of order fulfillment, the agile approach led to production levels being as close as possible to demand, with $89 \%, 99 \%, 99 \%$, and $98 \%$ of demand met by production for large batches with low and high variation and small batches with low and high variation, respectively. For the lean approach, order fulfillment was less stable, with $91 \%$ and $92 \%$ of demand met by production for large batches with low and high variation, respectively, and $107 \%$ and $111 \%$ of demand met by production for small batches with low and high variation, respectively. The BC-SC approach produced over the demand most of the time, with $96 \%$ and $108 \%$ of demand met by production for large batches with low and high variation, respectively, and $114 \%$ and $115 \%$ of demand met by production for small batches with low and high variation, respectively. Consequently, BC-SC was the worst at controlling lumber production. The flow time indicates the degree of responsiveness; thus, on average, the agile approach showed 10.4 periods; the BC-SC approach showed 11.7 periods, and the lean approach showed 12.2 periods of flow time. These results agree with Narasimhan et al. [26], who found higher delivery speeds and reliability for the agile approach compared with the lean approach (Figure 3, Tables A8 and A9 in the Appendix B). 


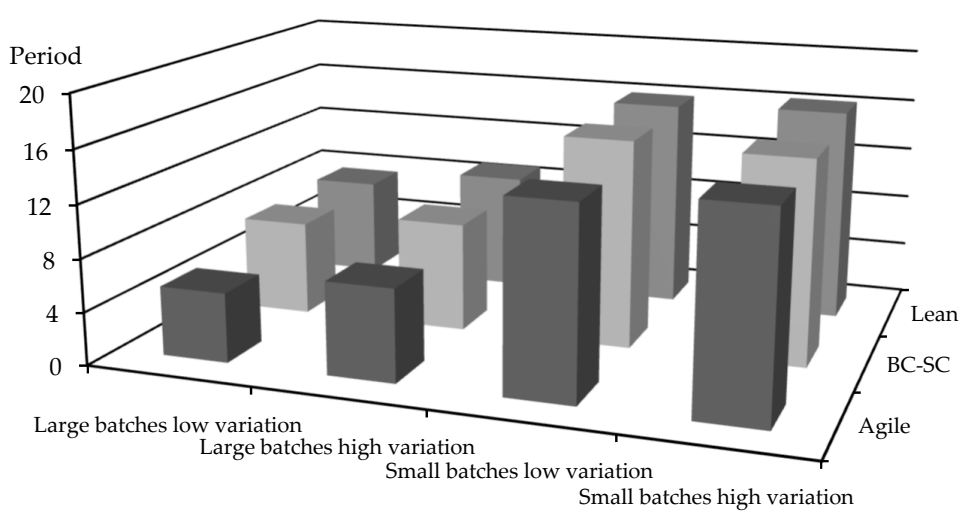

(a)

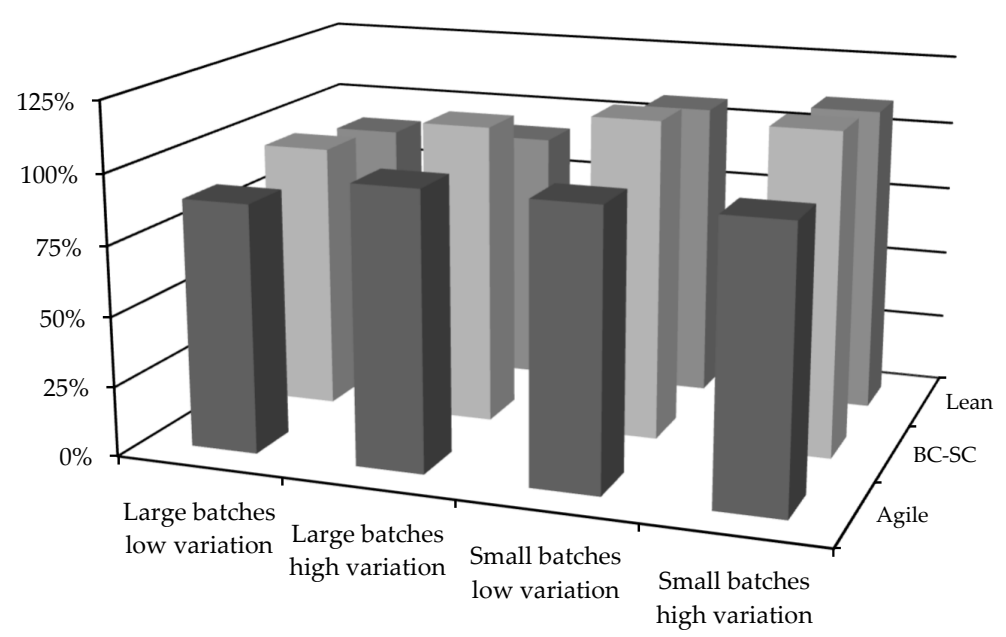

(b)

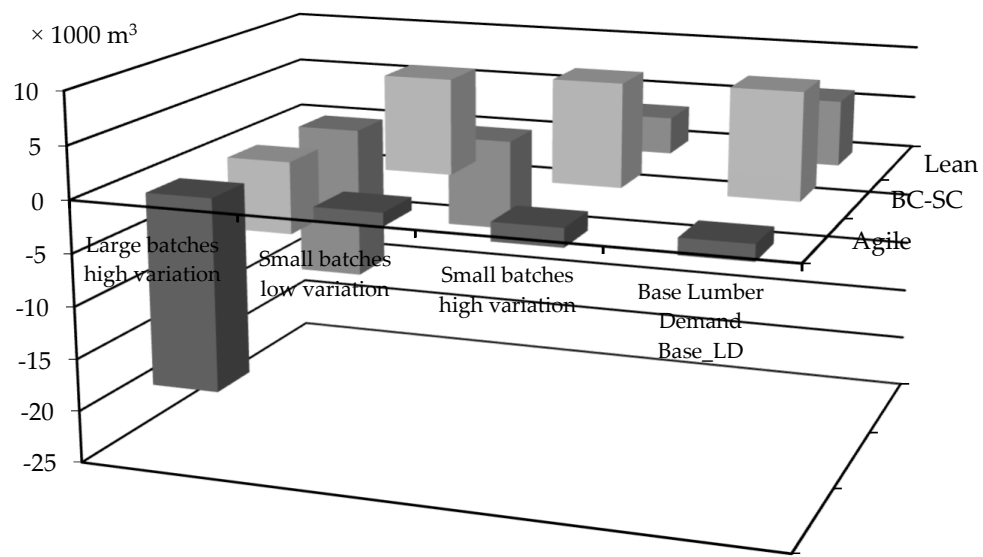

(c)

Figure 3. Flexibility parameters by ME and LDS, which should be listed as: (a) Flow time (periods), (b) Orders fulfillment (\%), and (c) Over-under lumber production $\times 1000 \mathrm{~m}^{3}$ ). 


\section{Discussion}

The industrial relevance of lean, agile, and hybrid manufacturing systems is clear, but there is a need to unpack these ambiguous terms, if integration of these conflicting paradigms is to be logically developed to meet specific business needs [27]. An analysis and discussion of tradeoffs based on variation, inventory, and capacity follows.

Our results can be compared with Goldsby et al. [1] with respect to the economic performance of MEs, although they used DES and we used MIP to model the SC. Nevertheless, both analyses determined the operational costs. The lowest costs were produced by the agile approach, followed by the lean approach ( $5 \%$ over) and the BC-SC approach ( $14 \%$ over). However, Goldsby et al. [1] showed only a small difference between the lean and agile costs (e.g., only $2 \%$ ) and a hybrid with $15 \%$ higher costs. Although the differences in percentages between our costs were larger, both results are close in terms of magnitudes and trends. Furthermore, we found that the operational costs agree with the results of [Narasimhan et al. [26], in which lean costs were the lowest, closely followed by agile costs. Goldsby et al. [1] analyzed the concept of the "order-to-ship time" as a customer service parameter. Also, Qrunfleh et al. [28] explored the ability of lean and agile systems to increase responsiveness and waste elimination. They found that an agile SC strategy contributes significantly to building SC responsiveness. Contrarily, no significant relationship between a lean SC strategy and SC chain responsiveness was found. However, a lean SC strategy has a significant relationship with waste elimination. In our study, we did not explicitly model delivery time, although order fulfillment or over/under production attempts to capture this. They stated that lean exhibits three times lower order-to-ship times than the hybrid (i.e., BC-SC) approach and eight times slower order-to-ship times compared to the agile approach, without mentioning backorder numbers. We considered customer service parameters as order fulfillments, as did Babazadeh et al. [7]. Nevertheless, our results show that the lean approach produced double the number of backorders of agile, which agrees with the results of Narasimhan et al. [26] and Enriquez et al. [29], which showed higher delivery speeds and delivery reliability for the agile approach over the lean approach. These experimental results are in great tuning with manager perceptions, which strongly believes that lean SC strategy is mostly focused on waste elimination rather that responsiveness improvement; this is the capital emphasis of agile SC strategy [28].

The lean supply paradigms perform better with a low variation of products enabling flow, and reducing the need for buffer or protective inventory and capacity. However, with the growth in products innovation and demand uncertainty, supply chains need to strategically locate inventory and capacity to enable the flow of production [27]. However, our results indicate that lean accumulates more inventories than agile. Also, Goldsby et al. [1] found more inventory in agile than in hybrid, but we found the opposite. The differences in inventory can be related to our over and under-demand lumber production constraints, which cannot be stated in a DES model as explicitly as in an MIP model. There are also ship-to-order and order fulfillment conceptual differences between the studies. However, our results for the order fulfillment, overproduction, and underproduction of lumber and inventory are in agreement with the results of Hallgren et al. [2], which showed that the lean approach had a significant impact on cost efficiency, while the agile approach did not. However, the agile approach had a higher delivery performance (e.g., order fulfillment).

In an effort to measure the impacts of demand variation and batch size, we tested the impact of lumber demand scenarios on MEs. Unfortunately, we found a few quantitative and theoretical research to compare with, so we can only benchmark our results with them. Our results show that the agile approach has the highest profit, closely followed by the lean and BC-SC approaches. Goldsby et al. [1] showed that the agile and lean approaches were equally cost-efficient, while the hybrid approach was by far the most expensive (the most cost-efficient ME was assumed to be the one with highest profits). Enriquez et al. [29] found that the agile system is more attractive when one of the demands is low and there is a high variation of demands, which is equivalent to small batches with high variation in our study. Our results showed that the agile and lean approaches continued to have 
higher profits than the BC-SC approach for large batches without considering the effect of demand variation. When lumber demand showed low variation, no change was observed between the agile and lean profits, while the profits of BC-SC decreased by half. These profits are comparable to those identified by Christopher et al. [6]. While the lean approach was expected to have higher profitability than the agile approach for this type of lumber demand, instead it showed the same costs as the agile approach. However, when lumber demand shows high variation, differences in profits were tiny, with the agile and BC-SC approach were leading profits, followed closely by the lean approach. These profits are in agreement with those of Christopher et al. [6]. The BC-SC approach had the highest profits for product demands characterized by high variation and high volumes.

For small batches, the agile approach had higher profits than the lean and BC-SC approaches, but with larger profit differences. Our results for high variation again agreed with those of Christopher et al. [6], who stated that "agile profitably responds to high variety and low volumes". However, for low variation, my results did not show that the BC-SC approach had a higher profit as Christopher et al. [6] suggested, probably because we did not explicitly work with mixed portfolios of demands, where the hybrid approach is supposed to perform better.

In compliance with the economic penalties used for over and under-demand and capacity usage deviations, the agile approach always showed lower costs than the lean approach, which was able to use more capacity and deviate farther from demand, while compromising costs. The BC-SC approach showed the highest costs because log demand was a forecasted average per period and was not exactly the required log demand. As a consequence, order fulfillment (\%) and lumber production deviations were higher than they were in the lean and agile approaches, where timber was pulled directly from sawmills every period.

The models determined the expected result patterns with an objective function as a central driver plus constraints as second order drivers. Although Al-Aomar et al. [8] claimed that lean objectives are in conflict and a multi-objective formulation is required, we showed that ME attributes, such as customer service, chase and level manufacturing strategies, can be modeled with MIP, as Babazadeh et al. [7] did when modeling the design of an agile SC. Alternatively, if agile, lean, and hybrid approaches are required to be measured in the short term, their stochastic shop floor techniques could be modeled with DES and VSM, and multi-objective techniques.

Lumber production outsourcing, interchanges of lumber between sawmills, over/under capacity usage, and over/under demand features increase the ability of our formulations to represent MEs. Although over/underproduction capacity usage penalties did not play a large role in costs, because their related constraints were too tight, these constraints actively helped to model chase and level manufacturing strategies. However, over/under demand lumber production constraints played a large role in relaxing and controlling order fulfillment and in controlling lumber production, which is another central feature of MEs [16].

For SC practitioners, the results of this research highlight the benefits that forest firms can capitalize if they consider the introduction of lean, agile, and hybrid SC strategies. However, SC managers should be aware of the nature of the lumber products demand before choosing any of them. Another aspect that should be kept in mind is that the type of SC can capitalize the benefits of the lean agile appraoch, and hybrid (leagile) manufacturing [30]. The ability of these managerial tools to improve SC performance has been identified. Business units containing corporate headquarters, sales and services groups, inventory and management groups, and production units are the SCs with higher advantages. Furthermore, there are other SC concepts that were not included in this research as postponement or supplier partnerships [28], which could add extra criteria for SC strategy selection.

\section{Conclusions}

Our research shows that MEs for the case studies can be modeled with a reasonable level of detail with MIP, and that these formulations react to the lumber demand scenarios, as stated in our 
objectives. Indeed, our results highlight how manufacturing drivers and demand attributes influence the economic performance of lean, hybrid, and agile approaches for the forest-to-lumber SC.

When suggesting that ME should be adopted for the particular case of integrated BC coastal forest-to-lumber SCs, the attributes of demand should be considered. When lumber demand is stable with low variation and large volumes, agile or lean principles should be adopted. However, when lumber demand is unstable with high variation and large volumes, hybrid or agile principles should be maintained. When lumber demand is unstable with high variation and small volumes, an agile approach clearly provides higher profits than any other ME. For the same conditions of lumber demand, but with low variation, the agile approach is recommended; however, further analysis is required, because a hybrid (i.e., BC-SC) approach is in theory supposed to be the most appropriate under these circumstances.

There is an opportunity to increase profits by $11.1 \%$ by adopting an agile approach when lumber demand is stable with low variation and large volumes. However, the opportunity for increased profits is zero under the same demand attributes, but with high variation. Contrarily, there is an opportunity to increase profits by $12.1 \%$ by adopting agile or lean approaches when lumber demand is stable with low variation and small volumes, and there is an opportunity to increase profits by $15.5 \%$ when lumber demand is unstable with high variation and small volumes. However, these profit increments are subject to over/under capacity and demand penalties, the lumber demand scenarios, and the exploratory nature of this work. These results are specific to our case studies and the over/under demand and production penalties we used.

Author Contributions: In following, the contribution of each author was described. First, C.D.P. helped in Methodology, in particular: models formulation discussion, and models implementation. Second, J.N. contribution was in Writing-Review and Editing. And third, F.P.V. was in charge of Conceptualization, Methodology, Validation, Data Curation, Investigation, Writing-Original Draft Preparation and Resources. In particular Vergara made: the mathematical programming formulation, the state of art elaboration, the case study data collection, the model implementation, results production, and model improvement. Vergara was also responsible of project funding management.

Funding: This research was funded by the Chilean Ministry of Education MECESUP program, grant number Meta 28.

Acknowledgments: The authors of this research would like to express our deep gratitude to: the Chilean Ministry of Education; the Forest Products Innovation FP Innovation, Lumber Manufacturing Department; the University of British Columbia, Forest Resources Department; and the University of Bio-Bio, Wood Engineering Department.

Conflicts of Interest: The author declare no conflict of interest.

\section{Appendix A}

The mathematical formulations aim to solve the lumber planning problem emulating our MEs, keeping in mind that the BC Coastal forest SC has 3 nodes: forest cut-block, sort-yards, and sawmills. First, the objective functions were stated: for lean $\left(1^{\mathrm{L}}\right)$, for agile $\left(1^{\mathrm{A}}\right)$, and for $\mathrm{BC}-\mathrm{SC}$, the problem was divided in timber procurement $\left(1^{\mathrm{T}}\right)$, and lumber production $\left(1^{\mathrm{W}}\right)$. Second, a set of common constraints for all problems were stated, with the full formulation as follows:

Table A1. Model's sub-index.

\begin{tabular}{cc}
\hline I & Cut-block \\
J & Growth \\
K & Species \\
L & Sort-yard \\
M & Bucking policy \\
N & Log grade \\
O & Sawmill \\
P & Sawing policy \\
Q & Sawn-woods products \\
R & Periods \\
\hline
\end{tabular}


Table A2. Operational and inventory costs.

\begin{tabular}{|c|c|}
\hline 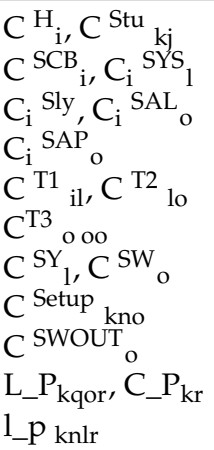 & $\begin{array}{l}\text { Harvesting cost }\left(\$ / \mathrm{m}^{3}\right) \text { at stand } \mathrm{i} \text {, and stumpage cost }\left(\$ / \mathrm{m}^{3}\right) \text { for species } \mathrm{k} \text {, growth } \mathrm{j} \text {. } \\
\text { Cost of keeping } 1 \mathrm{~m}^{3} \text { of stem at cut-block } \mathrm{i} \text {, and cost of keeping } 1 \mathrm{~m}^{3} \text { of stem at sort-yard } 1 \text {. } \\
\text { Cost of keeping } 1 \mathrm{~m}^{3} \text { of logs at sort-yard } 1 \text {, and sawmill o. } \\
\text { Cost of keeping } 1 \mathrm{~m}^{3} \text { of sawn wood products at sawmill o. } \\
\text { Transportation cost }\left(\$ / \mathrm{m}^{3}\right) \text { from stand i to sort yard } 1 \text {, and from sort yard } 1 \text { to sawmill o. } \\
\text { Transportation cost in } \$ / \mathrm{m}^{3} \text { of lumber from sawmill o to sawmill oo. } \\
\text { Sort-yard production cost }\left(\$ / \mathrm{m}^{3}\right) \text { in sort-yard } 1 \text {, and sawmilling cost }\left(\$ / \mathrm{m}^{3}\right) \text { in sawmill o. } \\
\text { Sawmill setup cost in } \$ \text {, charged when a sawmill changes species and log grade. } \\
\text { Outsourced sawmilling cost in } \$ / \mathrm{m}^{3} \text {, for sawmill o. } \\
\text { Lumber and chips price }\left(\$ / \mathrm{m}^{3}\right) \text { of species } \mathrm{k} \text {, product } \mathrm{q} \text {, sold by sawmill } \mathrm{o} \text {, in period } \mathrm{r} \text {. } \\
\text { Log price }\left(\$ / \mathrm{m}^{3}\right) \text { of species } \mathrm{k} \text {, grade } \mathrm{n} \text {, sort-yard l, in period } \mathrm{r} \text {. }\end{array}$ \\
\hline
\end{tabular}

Table A3. Yields, capacities and productivities.

\begin{tabular}{|c|c|}
\hline $\mathrm{Y}_{-} \mathrm{f}_{\mathrm{Ijk}}$ & Forest yield ( $\mathrm{m}^{3} / \mathrm{ha}$ ) in stand $\mathrm{i}$, of growth $\mathrm{j}$, and species $\mathrm{k}$. \\
\hline Y_syjkmn & Bucking yield (\%) of product $\mathrm{n}$ by stem growth $\mathrm{j}$, species $\mathrm{k}$, by applying bucking policy $\mathrm{m}$. \\
\hline Y_sw $w_{\text {knpq }}$ & Sawing yield (\%) of product $q$ by log grade $n$, species $k$, by applying sawing policy $p$. \\
\hline$Y_{-} \mathrm{ch}_{\mathrm{k}}{ }^{2}$ & Chipping yield (\%) of sawing sub-products species k. \\
\hline C_f $f_{r}, C \_s y_{r}, C \_s w_{r}$ & Harvesting, sort-yarding and sawmilling capacity (hours) on pe \\
\hline$P_{-} f_{j}$ & Logging productivity $\left(\right.$ hour $/ \mathrm{m}^{3}$ ) in a stand predominantly of g \\
\hline P_sy $y_{j k l}$ & Bucking-sorting productivity (hour $/ \mathrm{m}^{3}$ ) for stems of growth $\mathrm{j}$, species $\mathrm{k}$, at sort-yard 1 . \\
\hline P_sw $w_{j k l}$ & Sawing productivity (in hour $/ \mathrm{m}^{3}$ ) when sawing species $\mathrm{k}, \log$ grade $\mathrm{n}$, at sawmill $\mathrm{o}$. \\
\hline io_sys $j \mathrm{jl}$ & Zero inventory of stems of growth $\mathrm{j}$, species $\mathrm{k}$ at sort-yard 1 \\
\hline io_syl $\mathrm{knl}$ & Zero inventory of logs of species $k, \log$ grade $n$, at sort-yard 1 . \\
\hline io_sal kno $_{1}$ & Zero inventory of logs of species $\mathrm{k}, \log$ grade $\mathrm{n}$, at sawmill $\mathrm{o}$. \\
\hline io_sapkqo & Zero inventory of sawn-wood of species k, product q, at sawmill o. \\
\hline$D_{\text {kqor }}$ & Lumber demand $\left(\mathrm{m}^{3}\right)$ of species $\mathrm{k}$, product $\mathrm{q}$, in sawmill $\mathrm{o}$, for period $\mathrm{r}$. \\
\hline Log_D $D_{k n l r}$ & Logs demand $\left(\mathrm{m}^{3}\right)$ of species $\mathrm{k}, \log$ grade $\mathrm{n}$, in sort-yard $\mathrm{l}$, for period $\mathrm{r}$. \\
\hline
\end{tabular}

Table A4. Allowable quantities to penalize lumber production, capacity usage, and economic penalties.

\begin{tabular}{|c|c|}
\hline$\% O{ }_{\text {kqor }}, \% B \_1_{\text {kqor }}$ & $\begin{array}{l}\text { Max. \% for over/below production defined in function of the demand of lumber } \\
\text { product species } k \text {, product } q \text {, produced/sold by sawmill o, period } \mathrm{r} \text {. }\end{array}$ \\
\hline$\% O \_L O_{r}, \% B \_L O_{r}$ & $\begin{array}{l}\text { Max. over/below hours usage for logging in period } r \text {, defined as percentage of the } \\
\text { hours available in period } r \text {. }\end{array}$ \\
\hline$\% \mathrm{O} \_S Y_{1 \mathrm{r}}, \% \mathrm{~B} \_S Y_{\mathrm{lr}}$ & $\begin{array}{l}\text { Max. over/below hours usage for sort-yarding in sort-yard } 1 \text {, period } r \text {, defined as } \\
\text { percentage of the hours available in period } r \text {. }\end{array}$ \\
\hline$\% O \_S W_{\text {or }}, \% B \_S W_{\text {or }}$ & $\begin{array}{l}\text { Max. over/below hours usage for sawmilling in sawmill o, period } \mathrm{r} \text {, defined as } \\
\text { percentage of the hours available in period } \mathrm{r} \text {. }\end{array}$ \\
\hline PO_1 ${ }_{\mathrm{kqor}}, \mathrm{PB} \_1_{\mathrm{kqor}}$ & $\begin{array}{l}\text { Pct. of the lumber price of lumber product species } \mathrm{k} \text {, product } \mathrm{q} \text {, produced-sold by } \\
\text { sawmill o, period } \mathrm{r} \text {, to penalize } 1 \mathrm{~m}^{3} \text { produced over/below the lumber demand. }\end{array}$ \\
\hline PB_2 $k n l r$ & $\begin{array}{l}\text { Pct. of the } \log \text { price species } k, \log \text { grade } n \text {, produced-sold by sort-yard } 1 \text {, period } r \text {, } \\
\text { to penalize } 1 \mathrm{~m}^{3} \text { produced below the log demand. }\end{array}$ \\
\hline PO_LO, PB_LO & $\begin{array}{l}\text { Pct. of the logging cost charged for every over/below hour usage in logging } \\
\text { in period r. }\end{array}$ \\
\hline PO_SY$_{1 \mathrm{r}}, \mathrm{PB} \_S Y_{1 \mathrm{r}}$ & $\begin{array}{l}\text { Pct. of the sort-yarding cost charged for every over/below hour usage in } \\
\text { sort-yard l period } r \text {. }\end{array}$ \\
\hline PO_SW ${ }_{\text {or }}$, PB_SW or & $\begin{array}{l}\text { Pct. of the sawing cost charged for every over/below hour usage in sawing in } \\
\text { sawmill o, period } \mathrm{r} \text {. }\end{array}$ \\
\hline
\end{tabular}


Table A5. Decision variables.

\begin{tabular}{|c|c|}
\hline $\mathrm{H}_{\mathrm{ir}}$ & Land harvested (ha.) at stand $\mathrm{i}$, in period $\mathrm{r}$. \\
\hline $\mathrm{T}_{\mathrm{ijk} \mathrm{r}}$ & Harvested volume $\left(\mathrm{m}^{3}\right)$ at stand $i$, growth type $j$, species $k$ in period $r$. \\
\hline $\mathrm{I}_{\mathrm{Ijkr}}^{\mathrm{SCB}}$ & Inventory of stems $\left(\mathrm{m}^{3}\right)$ at cub-block $i$, of growth $j$, species $k$, in period $r$. \\
\hline $\mathrm{U}_{\mathrm{ijklr}}$ & Vol. of stems $\left(\mathrm{m}^{3}\right)$ of growth $\mathrm{j}$, species $\mathrm{k}$ sent from stand $\mathrm{i}$ to sort-yard $\mathrm{l}$, in period $\mathrm{r}$. \\
\hline $\mathrm{V}_{\mathrm{jklmr}}$ & Sort-yard 1 input of stems $\left(\mathrm{m}^{3}\right)$ of growth $\mathrm{j}$, species $\mathrm{k}$, bucked with policy $\mathrm{m}$, period $\mathrm{r}$. \\
\hline $\mathrm{I}^{\mathrm{SYS}}{ }_{\mathrm{jklr}}$ & Inventory of stems $\left(\mathrm{m}^{3}\right)$ of growth $\mathrm{j}$, species $\mathrm{k}$, at sort-yard $\mathrm{l}$, in period $\mathrm{r}$. \\
\hline $\mathrm{W}_{\mathrm{knlr}}$ & Vol. of $\operatorname{logs}\left(\mathrm{m}^{3}\right)$ of species $\mathrm{k}$, grade $\mathrm{n}$, produced in sort-yard $\mathrm{l}$ in period $\mathrm{r}$. \\
\hline $\mathrm{Y}_{\text {knopr }}$ & Vol. of logs $\left(\mathrm{m}^{3}\right)$ of species $\mathrm{k}$, grade $\mathrm{n}$, sawn with sawing policy $\mathrm{p}$, at sawmill $\mathrm{o}$, in period $\mathrm{r}$. \\
\hline $\mathrm{YO}_{\mathrm{knopr}}$ & $\begin{array}{l}\text { Vol. of logs }\left(\mathrm{m}^{3}\right) \text { of species } \mathrm{k} \text {, grade } \mathrm{n} \text {, sawn with sawing policy } \mathrm{p} \text {, at the outsourcing sawmill } \\
\text { of sawmill } \mathrm{o} \text {, in period } \mathrm{r} \text {. }\end{array}$ \\
\hline $\begin{array}{l}\mathrm{I}^{\mathrm{SAL}}{ }_{\text {knor }}, \mathrm{I}^{\mathrm{SYL}} \text { knlr } \\
\mathrm{X}_{\text {knlor }}\end{array}$ & $\begin{array}{l}\text { Inventory of } \operatorname{logs}\left(\mathrm{m}^{3}\right) \text { of species } \mathrm{k} \text {, grade } \mathrm{n} \text { at sawmill } \mathrm{o} \text { and at the sort yard } \mathrm{l} \text {, in period } \mathrm{r} \text {. } \\
\text { Vol. of } \operatorname{logs}\left(\mathrm{m}^{3}\right) \text { of species } \mathrm{k} \text {, grade } \mathrm{n} \text {, sent from sort-yard } 1 \text { to sawmill } \mathrm{o} \text {, in period } \mathrm{r} \text {. }\end{array}$ \\
\hline $\mathrm{Z}_{\mathrm{kqor}}$ & Vol. of lumber $\left(\mathrm{m}^{3}\right)$ of species $\mathrm{k}$, product $\mathrm{q}$, produced-sold by sawmill $\mathrm{o}$, in period $\mathrm{r}$. \\
\hline $\mathrm{ZO}_{\mathrm{kqor}}$ & $\begin{array}{l}\text { Vol. of lumber }\left(\mathrm{m}^{3}\right) \text { of species } \mathrm{k} \text {, product q, produced-sold by outsourced sawmill of } \\
\text { sawmill o, in } \mathrm{r} \text {. }\end{array}$ \\
\hline $\begin{array}{l}\text { ZI O_OO } \\
\text { ZI OO O O }\end{array}$ & Vol. of lumber $\left(\mathrm{m}^{3}\right)$ of species $\mathrm{k}$, product $\mathrm{q}$, arrived in interchanges to sawmill $\mathrm{o}$, in period $\mathrm{r}$. \\
\hline $\begin{array}{c}\text { ZI OO_O } \\
\text { DO_ } 1_{\text {kqoror }}, \text { DB_1 } 1_{\text {kqor }}\end{array}$ & $\begin{array}{l}\text { Vol. of lumber }\left(\mathrm{m}^{3}\right) \text { of species } \mathrm{k} \text {, product } \mathrm{q} \text {, sent in interchanges to sawmill } \mathrm{o} \text {, in period } \mathrm{r} \text {. } \\
\text { Vol. }\left(\mathrm{m}^{3}\right) \text { of over, below demand lumber production of species } \mathrm{k} \text {, product } \mathrm{q} \text {, produced-sold by } \\
\text { sawmill o in period } \mathrm{r} \text {. }\end{array}$ \\
\hline $\mathrm{DB} 1_{\mathrm{knlr}}$ & $\begin{array}{l}\text { Vol. }\left(\mathrm{m}^{3}\right) \text { of below demand log production of species } \mathrm{k}, \log \text { grade } \mathrm{n} \text {, produced-sold by sort } \\
\text { yard l, in period } \mathrm{r} \text {. }\end{array}$ \\
\hline DO_LO, DB_LO $r$ & Quantity of over/below cap. Usage (hours) in logging operation in period $\mathrm{r}$. \\
\hline DO_SY $1 \mathrm{r}, \mathrm{DB} \_S Y_{\text {lr }}$ & Quantity of over/below cap. Usage (hours) in sort-yarding operation at sort-yard $1 \mathrm{in}$ period $\mathrm{r}$. \\
\hline DO_SW $W_{\text {or }}, D B \_S W_{\text {or }}$ & Quantity of over/below cap. Usage (hours) in sawmilling operation at sawmill o in period r. \\
\hline $\mathrm{BA}_{\mathrm{kqor}}$ & Lumber balance $\left(\mathrm{m}^{3}\right)$ for species $\mathrm{k}$, product $\mathrm{q}$, produced-sold by sawmill $\mathrm{o}$, in period $\mathrm{r}$. \\
\hline $\mathrm{C}_{\mathrm{kr}}$ & Produced chips $\left(\mathrm{m}^{3}\right)$ of species $\mathrm{k}$ in period $\mathrm{r}$. \\
\hline $\mathrm{I}^{\mathrm{SAP}}$ kqor & Inventory of sawn-wood products $\left(\mathrm{m}^{3}\right)$ of species $\mathrm{k}$, sawn-wood products $\mathrm{q}$, in period $\mathrm{r}$. \\
\hline $\mathrm{LOT}_{\mathrm{r}}, \mathrm{SYT}_{\mathrm{lr}}, \mathrm{SWT}_{\mathrm{or}}$ & Logging time, Sort yard l processing time, and Sawmill o processing time in hours for period $\mathrm{r}$. \\
\hline$B Y_{\text {knor }}$ & ies $\mathrm{k}$, grade $\mathrm{n}$, in period $\mathrm{r}, 0$ otherwise. \\
\hline
\end{tabular}

Table A6. Objective functions.

\begin{tabular}{|c|c|}
\hline Notation & Description \\
\hline Minimization of costs $\left(\mathbf{1}^{1}\right)$ & $\begin{array}{l}=\text { Logging costs }+ \text { sort yarding costs }+ \text { sawmilling } \\
\text { costs }+ \text { cost to penalize below demand satisfaction }+ \\
\text { logging penalization cost }+ \text { sort yarding penalization } \\
\text { cost }+ \text { sawmilling penalizations costs }\end{array}$ \\
\hline Maximization of profit $\left(1^{a}\right)$ & $\begin{array}{l}=\text { Lumber and chips incomes-logging costs }- \text { sort } \\
\text { yarding costs }- \text { sawmilling costs }- \text { cost to penalize } \\
\text { below demand satisfaction }- \text { logging penalization } \\
\text { cost }- \text { sort yarding penalization cost - sawmilling } \\
\text { penalizations costs }\end{array}$ \\
\hline Minimization of timber procurement costs $\left(1^{\mathrm{T}}\right)$ & $\begin{array}{l}=\text { Logging costs }+ \text { sort yarding costs }+ \text { cost to penalize } \\
\text { below log demand satisfaction }+ \text { logging penalization } \\
\text { cost }+ \text { sortyarding penalization cost }\end{array}$ \\
\hline Maximization of lumber profits $\left(1^{\mathrm{W}}\right)$ & $\begin{array}{l}\text { =Lumber and chips incomes }- \text { cost of buying logs }- \\
\text { sawmilling costs }- \text { cost to penalize below lumber } \\
\text { demand satisfaction }- \text { sawmilling penalizations costs }\end{array}$ \\
\hline$\sum_{\mathrm{ijkr}} \mathbf{T}_{\mathrm{ijkr}} \mathrm{C}_{\mathrm{jk}}^{\mathrm{STU}}+\sum_{\mathrm{ijkr}} \mathbf{T}_{\mathrm{ijkr}} \mathrm{C}_{\mathrm{i}}^{\mathrm{H}}+\sum_{\mathrm{ijklr}} \mathbf{U}_{\mathrm{ijkklr}} \mathbf{T}_{\mathrm{il}}^{\mathrm{T} 1}+\sum_{\mathrm{ijkr}} \mathbf{I}_{\mathrm{ijkr}}^{\mathrm{SCB}} \mathrm{C}_{\mathrm{i}}^{\mathrm{SCB}}$ & $\begin{array}{l}=\text { Logging costs: harvesting costs, stumpage costs, } \\
\text { primary transportation cost, and stems } \\
\text { inventory costs }\end{array}$ \\
\hline$\sum_{\text {knlr }} W_{\text {knlr }} C_{1}^{S Y}+\sum_{\text {knlor }} X_{\text {knlor }} C_{l o}^{T 2}+\sum_{j k l} I_{j k l r}^{S Y S} C_{1}^{S Y S}+\sum_{\text {knlr }} I_{k n l r}^{S Y L} C_{1}^{S Y L}$ & $\begin{array}{l}\text { Sort yarding costs: sort yard processing cost, } \\
\text { transportation cost, and stems and logs costs }\end{array}$ \\
\hline 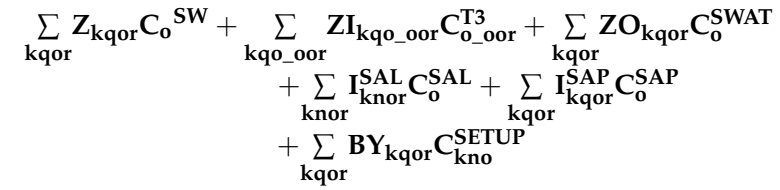 & $\begin{array}{l}\text { Sawmilling costs, including processing cost at } \\
\text { internal and outsourced sawmill, lumber production } \\
\text { swat, and logs and lumber inventory costs }\end{array}$ \\
\hline
\end{tabular}


Table A6. Cont.

\begin{tabular}{|c|c|}
\hline Notation & Description \\
\hline$\sum_{\text {kqor }} \mathbf{D B} \_\mathbf{1}_{\mathrm{kqor}} \mathrm{PB}_{\mathrm{kqor}}{\mathbf{L} \_\mathbf{P}_{\mathrm{kqor}}}$ & Cost to penalize below lumber demand satisfaction \\
\hline$\sum_{\mathrm{ir}} \mathrm{DO} \_\mathrm{LO}_{\mathrm{r}}\left[\mathrm{PO}_{-} \mathrm{LO}_{\mathrm{r}}\right] \mathrm{C}_{\mathrm{i}}^{\mathrm{H}}+\sum_{\mathrm{ir}} \mathrm{DB} \_\mathrm{LO}_{\mathrm{r}}\left[\mathrm{PB} \_\mathrm{LO}_{\mathrm{r}}\right] \mathrm{C}_{\mathrm{i}}^{\mathrm{H}}$ & Logging penalization costs \\
\hline$\sum_{\text {lr }} \mathrm{DO} \_S Y_{1 \mathrm{lr}}\left[\mathrm{PO} \_S Y_{1 \mathrm{lr}}\right] \mathrm{C}_{\mathrm{lr}}^{\mathrm{SY}}+\sum_{\mathrm{lr}} \mathrm{DB} \_S Y_{1 \mathrm{r}}\left[\mathrm{PB} \_S Y_{\mathrm{r}}\right] \mathrm{C}_{\mathrm{lr}}^{\mathrm{SY}}$ & Sort yarding penalization costs \\
\hline$\sum_{\text {or }} \mathrm{DO} \_S W_{\text {or }}\left[\mathrm{PO} \_S W_{\text {or }}\right] \mathrm{C}_{\text {or }}^{\mathrm{SW}}+\sum_{\text {or }} \mathrm{DB} \_\mathrm{SW}_{\mathrm{or}}\left[\mathrm{PB} \_\mathrm{SW}\right.$ or $] \mathrm{C}_{\mathrm{or}}^{\mathrm{SW}}$ & Sawmilling penalization costs \\
\hline 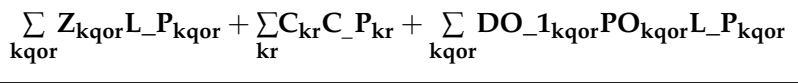 & $\begin{array}{l}\text { Lumber and chips incomes: includes lumber incomes, } \\
\text { chips incomes, and over demand production incomes }\end{array}$ \\
\hline$\sum_{\mathrm{knlr}} \mathrm{DB} 1_{\mathrm{knlr}} \mathbf{P B} \_\mathbf{2}_{\mathrm{knlr}} \mathbf{1} \_\mathbf{p}_{\mathrm{knlr}}$ & Cost to penalize below log demand satisfaction \\
\hline$\sum_{\text {kqor }} \mathbf{D B}_{\mathbf{k q o r}} \mathbf{P B}_{\mathrm{kqor}} \mathbf{L}_{-} \mathbf{P}_{\mathrm{kqor}}$ & Cost to penalize below lumber demand satisfaction \\
\hline$\sum_{k n l r} W_{k n l r} l p_{k n l r}$ & Costs of buying logs \\
\hline
\end{tabular}

Table A7. Constraints of the models.

$$
\begin{aligned}
& \sum H_{i r} \leq A_{i} \quad \forall \mathrm{i} \\
& \mathrm{T}_{i j k r}=H_{i r} Y_{-} \mathrm{f}_{i j k} \quad \forall \mathrm{i}, \mathrm{j}, \mathrm{k}, \mathrm{r} \\
& \sum_{i j k} T_{i j k r} P_{-} \mathrm{f}_{j} \leq \mathrm{C}_{-} \mathrm{f}_{r} \quad \forall r \\
& L O T_{r}=\sum_{i j k} T_{i j k r} \mathrm{P}_{-} \mathrm{f}_{j} \quad \forall \mathrm{r}
\end{aligned}
$$

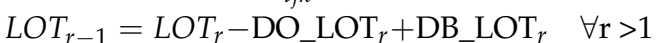

$$
\begin{aligned}
& \text { DO_LOT1 } 1_{r} \leq\left[\% \%_{-} L O T 1_{r}\right] \mathrm{C}_{-} \mathrm{f}_{r} \quad \forall \mathrm{r} \\
& \text { DB_LOT1 } 1_{r} \leq\left[\% \%_{-} \_O T 1_{r}\right] \text { C_f } f_{r} \quad \forall \mathrm{r}>1 \\
& \text { DO_SYT1 } 1_{l r} \leq\left[\% O \_S Y T 1_{r}\right] \text { C_sy }{ }_{l r} \quad \forall l, \mathrm{r} \\
& \text { DB_SYT1 } 1_{l r} \leq\left[\% \%_{-} \_S Y T 1_{r}\right] \text { C_sy } y_{l r} \quad \forall l, \mathrm{r} \\
& \text { DO_SWT1 } 1_{o r} \leq\left[\% O \_S W T 1_{r}\right] \text { C_sw }{ }_{\text {or }} \quad \forall o, \mathrm{r} \\
& \text { DB_SWT1 } 1_{\text {or }} \leq\left[\% \text { B_SWT } 1_{r}\right] \text { C_sw } \text { or } \quad \forall o, r \\
& T_{i j k r}+I_{i j k r-1}^{S C B}-I_{i j k r}^{S C B}=\sum_{l} U_{i j k l r} \quad \forall \mathrm{i}, \mathrm{j}, \mathrm{k}, \mathrm{r} \\
& \sum_{i} U_{i j k l r}+I_{i j k l r-1}^{S Y S}-I_{i j k l r}^{S Y S}=\sum_{m} V_{j k l m r} \quad \forall \mathrm{j}, \mathrm{k}, \mathrm{l}, \mathrm{r} \\
& \sum_{j m} V_{j k l m r} Y_{-} s y_{j k m n}=W_{k n l r} \quad \forall \mathrm{k}, \mathrm{n}, \mathrm{l}, \mathrm{r} \\
& \sum_{j k m} V_{j k m} P \_s y_{j k l} \leq C_{-} s y_{l r} \quad \forall 1, \mathrm{r} \\
& S Y T_{l r}=\sum_{j k m} V_{j k l m r} P_{-} s y_{j k l} \quad \forall 1, \mathrm{r} \\
& S Y T_{l r-1}=S Y T_{l r}-\text { DO_SYT1 } 1_{l r}+\text { DB_SYT1 } 1_{l r} \quad \forall 1, r>1 \\
& W_{k n l r}+I_{k n l r-1}^{S Y L}-I_{k n l r 1}^{S Y L}=\sum_{j m} V_{j k l m r} Y_{-} s y_{j k m n} \quad \forall \mathrm{k}, \mathrm{n}, \mathrm{l}, \mathrm{r} \\
& \sum_{l} X_{k n l o r}+I_{k n o r-1}^{S A L}-I_{k n o r}^{S A L}=\sum_{p} Y_{k n o p r}+\sum_{p} Y O_{k n o p r} \quad \forall \mathrm{k}, \mathrm{n}, \mathrm{o}, \mathrm{r} \\
& \sum_{n p} Y_{k n o p r} Y_{-} s w_{k n p q}=Z_{k q o r} \quad \forall \mathrm{k}, \mathrm{q}, \mathrm{o}, \mathrm{r} \\
& \sum_{n p} Y O_{k n o p r} Y_{-} s w_{k n p q}=Z O_{k q o r} \quad \forall \mathrm{k}, \mathrm{q} \text {, or } \\
& \sum_{p} Y O_{k n o p r} \leq B Y_{k q o r} 1,000,000 \quad \forall \mathrm{k}, \mathrm{n}, \mathrm{o}, \mathrm{r} \\
& \sum_{q 0} Z_{k q o r} Y_{-} c h_{k}=C_{k r} \quad \forall \mathrm{k}, \mathrm{r} \\
& \sum_{k q} Z_{k q o r} P_{-} s w_{0} \leq C_{-} s w_{o r} \quad \forall \mathrm{o}, \mathrm{r} \\
& \mathrm{ZO}_{\text {kqor }} P \_s w_{0} \leq 20 \% C_{-} s w_{o r} \quad \forall \mathrm{o}, \mathrm{r} \\
& S W T_{o r}=\sum_{k q} Z_{k q o r} P \_s w_{o} \quad \forall \mathrm{o}, \mathrm{r} \\
& \sum_{k q o r} Z_{\text {kqor }} \leq \sum_{\text {kqor }} Z_{k q o r} \quad \forall \mathrm{r}
\end{aligned}
$$


Table A7. Cont.

$$
\begin{aligned}
& \begin{array}{c}
S W T_{\text {or-1 }}=S W T_{\text {or }}-\mathrm{DO} \_S W T 1_{\text {or }}+\mathrm{DB} \_S W T 1_{\text {or }} \quad \forall \mathrm{o}, \mathrm{r}>1 \\
Z_{k q o r}+Z O_{k q o r}+I_{k q o r-1}^{S A P}-I_{k q o r}^{S A P}-D D_{-} 1_{k q o r}+D B_{-} 1_{k q o r}-\sum_{\text {ooo }} Z I_{k q o o o r}+\sum_{o a} Z I_{k q o a o r}=D_{k q o r} \quad \forall q k o r
\end{array} \\
& B A_{k q o r}=Z_{k q o r}+Z O_{k q o r}+I_{k q o r-1}^{S A P}-I_{k q o r}^{S A P}-\sum_{o o} Z I_{k q o \_o o r}+\sum_{o a} Z I_{k q o a \_o r} \quad \forall \mathrm{k}, \mathrm{q}, \mathrm{o}, \mathrm{r} \\
& \text { ZI_O_OO } I_{\text {kgor }}=\sum_{o O} Z I_{\text {kqoo_or }} \quad \forall \mathrm{k}, \mathrm{q}, \mathrm{o}, \mathrm{r} \\
& \text { ZI_OO_O } \mathrm{O}_{\text {kqor }}=\sum_{\text {oo }} Z_{\text {kqo_oor }} \quad \forall \mathrm{k}, \mathrm{q}, \mathrm{o}, \mathrm{r} \\
& \text { DO_1 } 1_{\text {kqor }} \leq\left[\% O{ }_{0} 1_{k q o r}\right] D_{k q o r} \quad \forall \mathrm{k}, \mathrm{q}, \mathrm{o}, \mathrm{r} \\
& D B \_1_{k q o r} \leq\left[\%{ }_{-} 1_{k q o r}\right] D_{k q o r} \quad \forall \mathrm{k}, \mathrm{q}, \mathrm{o}, \mathrm{r} \\
& I_{i j k r}^{S C B} \geq 0, I_{k n l r}^{S Y L} \geq 0, I_{k n o r}^{S A L} \geq 0, I_{k q o r}^{S A P} \geq 0 \quad \forall \mathrm{i}, \mathrm{j}, \mathrm{k}, \mathrm{n}, \mathrm{l}, \mathrm{q}, \mathrm{o}, \mathrm{r}=4
\end{aligned}
$$

Constraint 1 ensures that all period cut-block harvests do not exceed the cut-block area. Constraint 2 computes the cut-block volume harvested, and constraint 3 limits the time expended in logging. As I constrained the rate of capacity usage between periods, constraint 4 computes the time used for logging per period and constraint 5 adds slack variables to track logging time deviations between periods. The same principle was applied for sort-yards and sawmills (constraints 5-11). Several flow balance constraints were applied on the: logging side, sort-yard side, and internal and outsourced sawmills side $(12,13,18$, and 19). Constraint 14 determined log productions at the sort-yards. Constraint 15 limits the time expended in sort-yarding. Constraint 16 calculated the time used at sort-yards per period, and constraint 17 works in the same fashion as constraint 5 . Constraints 20-21 determined the lumber production at internal and outsourced sawmills. A setup cost was applied when sawmills changed log species and grades; thus, a binary variable, which is 1 if log species and grades are changed, and zero otherwise (constraint 22).

The chips produced are determined by constraint 23 . Constraint 24 limits the time expended in sawmilling. Constraint 25 limits the time expended in outsourcing sawmilling to $20 \%$ of the available period's sawmilling capacity, and constraint 27 ensures that internal sawmill production will not be exceeded by outsourced sawmill production. As I constrained the deviations of capacity usage between periods, constraint 26 computes the time used on sawmilling per period. Constraint 28 limited the sawmilling time deviations between periods by adding slack variables. A market constraint 29 ensured that lumber demand would be satisfied with all sources of lumber production. Balance constraint 30 determined the volume of lumber to be considered for order fulfillment parameter calculations. Constraints 31-32 determined the volume of lumber that arrived in interchanges from other sawmills to sawmill "o" and determined the lumber that is sent to other sawmills from sawmill "o." Constraint 33 ensured that the amount of lumber produced over demand will not exceed a given [\%] of the lumber demand. Constraint 34 ensured that the amount of lumber produced below the demand will not exceed a given [\%] of the lumber demand. Constraints 35-38 ensured that the final inventories are positive.

Furthermore, several parameters calculated were not included in the formulations, but brief explanations follow. Process flow time is the ratio between the inventory and the process throughput. Over/under production is the difference between lumber production and demand. Order fulfillment is the ratio between lumber production and demand. Procurement cost is the ratio between the summation of all costs prior to the sawmill log yard and the logs produced by sort-yards. Manufacturing cost is the ratio between the summation of all costs after logs are fed to the sawmills and the lumber produced.

The agile objective function $\left(1^{\mathrm{A}}\right)$ maximizes profit and the lean objective function $\left(1^{\mathrm{L}}\right)$ minimizes costs. Both objective functions operate on the same feasible region (convex hull defined by Equations (2-35)). Therefore, $1^{\mathrm{A}}$ will always dominate $1^{\mathrm{L}}$. However, this dominance is minimized by the use of penalty coefficients for over/under production and order fulfillment. The penalty values are important components of the models and strongly influence how they behave. They were discussed further when the results were presented. 


\section{Appendix B}

Table of Results

Table A8. Summary of economics by lumber demand scenario (LDS) and manufacturing environment (ME) (in millions of CAD).

\begin{tabular}{|c|c|c|c|c|c|c|c|c|c|c|c|c|c|c|c|}
\hline \multirow{2}{*}{$\begin{array}{c}\text { LDS } \\
\mathrm{ME}\end{array}$} & \multicolumn{3}{|c|}{ Base } & \multicolumn{3}{|c|}{$\begin{array}{c}\text { Large Batches Low } \\
\text { Variation }\end{array}$} & \multicolumn{3}{|c|}{$\begin{array}{l}\text { Large Batches High } \\
\text { Variation }\end{array}$} & \multicolumn{3}{|c|}{$\begin{array}{c}\text { Small Batches Low } \\
\text { Variation }\end{array}$} & \multicolumn{3}{|c|}{$\begin{array}{c}\text { Small Batches High } \\
\text { Variation }\end{array}$} \\
\hline & Agile & Hybrid & Lean & Agile & Hybrid & Lean & Agile & Hybrid & Lean & Agile & Hybrid & Lean & Agile & Hybrid & Lean \\
\hline Profit & 19,671 & 20,402 & 18,869 & 21,084 & 18,736 & 20,921 & 17,976 & 17,857 & 17,505 & 13,550 & 11,904 & 12,721 & 13,562 & 11,465 & 12,471 \\
\hline Incomes & 34,264 & 34,443 & 33,454 & 42,977 & 43,155 & 42,184 & 29,763 & 29,949 & 29,013 & 18,368 & 18,635 & 18,437 & 17,842 & 18,074 & 17,961 \\
\hline $\begin{array}{l}\text { Procurement } \\
\text { cost }\end{array}$ & 10,643 & 11,821 & 10,326 & 14,879 & 18,993 & 15,291 & 8938 & 8577 & 7920 & 3080 & 5999 & 4743 & 2607 & 5983 & 4864 \\
\hline $\begin{array}{c}\text { Manufacturing } \\
\text { cost }\end{array}$ & 2226 & 2574 & 2187 & 2899 & 3205 & 2902 & 2035 & 2357 & 1826 & 1299 & 1717 & 1340 & 1181 & 1573 & 1323 \\
\hline $\begin{array}{l}\text { Over-below } \\
\text { cap. Cost }\end{array}$ & 15 & 14 & 11 & 28 & 21 & 11 & 11 & 15 & 11 & 4 & 8 & 13 & 5 & 11 & 13 \\
\hline $\begin{array}{l}\text { Penalized } \\
\text { incomes }\end{array}$ & 121 & 1068 & 0 & 468 & 798 & 915 & 311 & 1189 & 70 & 210 & 1147 & 897 & 182 & 1186 & 1090 \\
\hline Penalty cost & 1830 & 1034 & 2061 & 4555 & 2903 & 3975 & 1114 & 316 & 1821 & 644 & 0 & 516 & 671 & 0 & 380 \\
\hline All cost & 14,714 & 15,442 & 14,585 & 22,361 & 25,122 & 22,179 & 12,098 & 11,265 & 11,578 & 5028 & 7724 & 6613 & 4463 & 7566 & 6579 \\
\hline Variation (\%) & $0 \%$ & $-5 \%$ & $1 \%$ & $0 \%$ & $-11 \%$ & $-1 \%$ & $0 \%$ & $-1 \%$ & $-3 \%$ & $0 \%$ & $-12 \%$ & $-6 \%$ & $0 \%$ & $-15 \%$ & $-8 \%$ \\
\hline
\end{tabular}

Table A9. Supply chain performance metrics by lumber demand scenario (LDS) and manufacturing environment (ME).

\begin{tabular}{|c|c|c|c|c|c|c|c|c|c|}
\hline \multirow{2}{*}{$\begin{array}{c}\text { SC Performance Indicator } \\
\mathrm{ME} / \mathrm{LDS}\end{array}$} & \multicolumn{3}{|c|}{ Flow Time (Periods) } & \multicolumn{3}{|c|}{ Orders Fulfillment (\%) } & \multicolumn{3}{|c|}{ Over-Under Lumber Production $\left(\mathrm{m}^{3}\right)$} \\
\hline & Agile & Hybrid & Lean & Agile & Hybrid & Lean & Agile & Hybrid & Lean \\
\hline Large batches low variation & 5.26 & 7.19 & 7.53 & $89 \%$ & $96 \%$ & $91 \%$ & $(18,393)$ & (7184) & $(15,417)$ \\
\hline Large batches high variation & 6.98 & 8.28 & 8.98 & $99 \%$ & $108 \%$ & $92 \%$ & $(1253)$ & 9100 & $(9073)$ \\
\hline Small batches low variation & 14.28 & 15.75 & 15.95 & $99 \%$ & $114 \%$ & $107 \%$ & $(1756)$ & 9744 & 3515 \\
\hline Small batches high variation & 15.14 & 15.45 & 16.28 & $98 \%$ & $115 \%$ & $111 \%$ & $(1534)$ & 10,258 & 6222 \\
\hline Base lumber demand & 5.73 & 6.19 & 8.14 & $94 \%$ & $103 \%$ & $91 \%$ & (7409) & 3993 & $(11,170)$ \\
\hline
\end{tabular}




\section{References}

1. Goldsby, T.; Griffis, S.; Roath, A. Modeling lean, agile and leagile supply chain strategies. J. Bus. Logist. 2006, 27, 57-80. [CrossRef]

2. Hallgren, M.; Olhager, J. Lean and agile manufacturing: External and internal drivers and performance outcomes. Int. J. Oper. Prod. Manag. 2009, 29, 976-999. [CrossRef]

3. Naylor, B.; Nain, M.; Berry, D. Leagility: Integrating the lean and agile manufacturing paradigms in the total supply chain. Int. J. Prod. Econ. 1999, 62, 107-118. [CrossRef]

4. Gunasekaran, A. Agile manufacturing: A framework for research and development. Int. J. Prod. Econ. 1999, 62, 87-105. [CrossRef]

5. Chopra, S.; Meindl, P. Supply Chain Management: Strategy, Planning and Operation, 1st ed.; Prentice Hall College Division: Englewood, NJ, USA, 2000.

6. Christopher, M. The Agile Supply Chain Competing in Volatile Markets. Ind. Mark. Manag. 2000, $29,37-44$. [CrossRef]

7. Babazadeh, R.; Razni, J.; Ghodsi, R. Supply chain network design problem for a new market opportunity in an agile manufacturing system. J. Ind. Eng. Int. 2012, 8, 8-19. [CrossRef]

8. Al-Aomar, R. Handling multi-lean measures with simulation and simulating annealing. J. Frankl. Int. 2011, 348, 1506-1522. [CrossRef]

9. Huang, S.; Uppal, M.; Shi, F. A products driven approach to manufacturing supply chain selection. Supply Chain Manag. Int. J. 2002, 7, 189-199. [CrossRef]

10. Sipper, D.; Bulfin, R. Production Planning, Control, and Integration; McGraw-Hill: New York, NY, USA, 1997.

11. Hege, L.; Gicquel, C.; Minoux, M. Lagrangian Relaxation for Multi-Level Lotsizing Problems; ROADEF: Toulouse, France, 2010.

12. Billington, P.J.; McClain, J.O.; Thomas, L.J. Mathematical programming approaches to capacity-constrained MRP systems: Review, formulation and problem reduction. Manag. Sci. 1983, 29, 1126-1141. [CrossRef]

13. Hung, Y.F.; Chien, K.L. A multi-class multi-level capacitated lot sizing model. J. Oper. Res. Soc. 2000, 51, 1309-1318. [CrossRef]

14. Yang-Hua, L.; van Landeghem, H. An application of simulations and value stream mapping in lean manufacturing. Presented at the 14th European Simulation Symposium, Dresden, Germany, 23-26 October 2002.

15. Aldulmalek, F.; Rajgopal, J. Analyzing the benefits of lean manufacturing and value stream mapping via simulation: A process sector case study. Int. J. Prod. Econ. 2007, 107, 223-236. [CrossRef]

16. Paine, T.; Peters, M.J. What is the right supply chain for your products? Int. J. Logist. Manag. 2004, 15, 77-92. [CrossRef]

17. Mason-Jones, R.; Naim, M.M.; Towill, D.R. The impact of pipeline control on supply chain dynamics. Int. J. Logist. Manag. 1997, 8, 47-62. [CrossRef]

18. Mason-Jones, R.; Towill, D.R. Using the information decoupling point to improve supply chain performance. Int. J. Logist. Manag. 1999, 10, 13-26. [CrossRef]

19. Bruce, M.; Dayl, L. Lean or agile, a solution for supply chain management in the textiles and clothing industry? Int. J. Oper. Prod. Manag. 2004, 24, 151-170. [CrossRef]

20. Christopher, M.; Towill, D. An integrated model for the design of agile supply chains. Int. J. Phys. Distrib. Logist. Manag. 2001, 31, 235-246. [CrossRef]

21. Carvalho, H.; Barroso, A.P.; Machado, V.H.; Azevedo, S.; Cruz-Machado, V. Supply chain redesign for resilence using simulation. Comput. Ind. Eng. 2012, 62, 329-341. [CrossRef]

22. Haartveit, E.; Kozak, R.; Maness, T. Supply chain management mapping for the forest products industry: Three cases from western Canada. J. For. Prod. Bus. Res. 2004, 1, 1-30.

23. Salehirad, N.; Sowlati, T. Performance of primary wood producers in British Columbia using data envelopment analysis. Can. J. For. Res. 2005, 34, 285-294. [CrossRef]

24. Western Forest Products Inc. 2010, 2011, and 2012, Annual Information Form. Available online: http:/ / www.westernforest.com/ (accessed on the 8 October 2013).

25. Agarwal, A.; Shankar, R.; Tiwari, M.K. Modeling the metrics of lean, agile and leagile supply chain: An ANP-based approach. Eur. J. Oper. Res. 2006, 173, 211-225. [CrossRef]

26. Narasimhan, R.; Swink, M.; Kim, S.W. Disentangling leanness and agility: An empirical investigation. J. Oper. Manag. 2006, 24, 440-457. [CrossRef] 
27. Stratton, R.; Warburton, R.D.H. The strategic integration of agile and lean supply. Int. J. Prod. Econ. 2003, 85, 183-198. [CrossRef]

28. Qrunfleh, S.; Tarafdar, T. Lean and agile supply chain strategies and supply chain responsiveness: The role of strategic supplier partnership and postponement. Supply Chain Manag. Int. J. 2013, 18, 571-582. [CrossRef]

29. Enriquez, N.S.; Haw, J.I.; Tam, K.E.; Cruz, D.E. A Supply Chain Model for Lean Facilities Considering Milk Round Replenishment, Postponement Production System and One-For-One Base Stock Inventory Policy Decision. In Proceedings of the 2011 International Conference on Industrial Engineering and Operations Management (IEOM), Kuala Lumpur, Malaysia, 22-24 January 2011; pp. 500-504.

30. Krishnamurthy, R.; Yauch, C.A. Leagile manufacturing: A proposed corporate infrastructure. Int. J. Oper. Prod. Manag. 2007, 27, 588-604. [CrossRef]

(C) 2018 by the authors. Licensee MDPI, Basel, Switzerland. This article is an open access article distributed under the terms and conditions of the Creative Commons Attribution (CC BY) license (http://creativecommons.org/licenses/by/4.0/). 